\title{
Synchronized sexual reproduction of the seagrass Syringodium filiforme (Cymodoceaceae) in a tropical reef lagoon on the Caribbean coast of Costa Rica
}

\section{Reproducción sexual sincronizada del pasto marino Syringodium filiforme (Cymodoceaceae) en la laguna de un arrecife tropical en la costa Caribe de Costa Rica}

\author{
Jimena Samper-Villarreal ${ }^{*}$, Margarita Loría-Naranjo ${ }^{1}$, Brigitta I. van Tussenbroek ${ }^{2}$ \& \\ Jorge Cortés ${ }^{1,3}$
}

\begin{abstract}
There has been an increasing effort to understand the mechanisms of sexual reproduction in seagrasses, which is usually synchronized. Synchronization is caused by environmental cues, such as temperature and light availability, and most likely occurs to maximize pollination success. At higher latitudes where seagrass reproductive seasons are clearly marked, intraannual variability of environmental triggers is significant. Our aim was to identify the period and frequency of sexual reproduction for the manatee grass Syringodium filiforme in a tropical coral reef lagoon, where the above-mentioned environmental triggers are homogenous all year round. The reproductive state and frequency and shoot length of S. filiforme were measured non-destructively in a monospecific patch on the tropical Caribbean coast of Costa Rica. The meadow was surveyed at 1 to 4-month intervals between May 2010 and May 2012. Water turbidity, temperature, and salinity were measured in situ. During the surveyed period, sexual reproduction of $S$. filiforme was detected in February and May, while seagrass shoot length showed no variation. The moment of seagrass sexual reproduction was not fully explained by the environmental parameters studied. Regardless of the limited environmental variability compared to previous studies at higher latitudes, synchronization of seagrass sexual reproduction at this tropical location is interesting and requires further studies on mechanisms and its possible adaptive advantage.
\end{abstract}

Keywords: flowering, manatee grass, marine angiosperms, phenology, reproductive cymes

1 Centro de Investigación en Ciencias del Mar y Limnología (CIMAR), Ciudad de la Investigación, Universidad de Costa Rica, San Pedro, 11501-2060 San José, Costa Rica; jimena.sampervillarreal@ucr.ac.cr* ORCID: https:// orcid.org/0000-0002-7513-7293; maggie.loria@gmail.com ORCID: https://orcid.org/0000-0003-4396-7388, jorge. cortes@ucr.ac.cr ORCID: https://orcid.org/0000-0001-7004-8649

2 Unidad Académica Sistemas Arrecifales-Puerto Morelos, Instituto de Ciencias del Mar y Limnología, Universidad Nacional Autónoma de México, México; vantuss@cmarl.unam.mx ORCID: https://orcid.org/0000-0002-6447-7479

3 Escuela de Biología, Universidad de Costa Rica, San Pedro, 11501-2060 San José, Costa Rica 


\section{RESUMEN}

Ha habido un incremento en los esfuerzos por entender los mecanismos de reproducción sexual en pastos marinos, la cual usualmente ocurre de manera sincronizada. Se considera que esta sincronización se da para maximizar el éxito de la polinización. Esta sincronización en la reproducción sexual de pastos marinos es inducida por señales ambientales, como la temperatura y disponibilidad de luz. A mayores latitudes, donde los pastos marinos tienen períodos de reproducción estacional marcados, la variabilidad interanual de estas señales ambientales es significativa. Nuestro objetivo fue identificar el período de tiempo y frecuencia de reproducción sexual del pasto de manatí, Syringodium filiforme, en una laguna de arrecife tropical, donde los factores ambientales mencionados son homogéneos a lo largo del año. El estado y frecuencia reproductiva, así como la longitud de los haces, de S. filiforme se midieron de manera no destructiva en un parche monoespecífico de una pradera en la costa Caribe de Costa Rica. Esta pradera se muestreó en intervalos de 1 a 4 meses entre mayo del 2010 y mayo del 2012. La turbidez del agua, temperatura y salinidad se midieron in situ. Nuestro estudio identificó reproducción sexual durante el período de muestreo para $S$. filiforme en febrero y mayo en el sitio de estudio; mientras que la longitud de haces no evidenció variación. El momento de reproducción sexual de pasto marino no fue explicado de lleno por los parámetros ambientales estudiados. Su sincronización en esta ubicación tropical, a pesar de contar con variabilidad ambiental limitada en comparación con estudios previos a mayores latitudes, es interesante y amerita más investigación sobre los mecanismos y la posible ventaja adaptativa de la reproducción sexual sincronizada en pastos marinos.

Palabras clave: floración, manatí, angiospermas marinas, fenología, cimas reproductivas

\section{INTRODUCTION}

Seagrass meadows provide many ecosystem services, including serving as nursery grounds, contributing to carbon sequestration, supporting complex food webs, and enhancing coastal stability (Orth et al. 2006a; Nordlund et al. 2018; James et al. 2019). Despite their acknowledged importance, seagrass meadows are declining worldwide (Waycott et al. 2009). For instance, recent evidence shows seagrass declining in the Caribbean (Van Tussenbroek et al. 2014).

Seagrasses are flowering plants that produce seeds, though most populations can be maintained exclusively through clonal spread by fragmentation and rhizome elongation (Walker et al. 2001; Kendrick et al. 2005; Ackerman, 2006; Kendrick et al. 2012). Several decades ago, sexual reproduction was considered unimportant. However, new genetic studies and the development of new markers have now revealed higher seagrass genetic variability than what was previously thought, leading to a new paradigm of sexual reproduction with a more significant role in seagrass population dynamics (Marbà \& Walker, 1999; Waycott et al. 2006; Van Tussenbroek et al. 2009). Sexual reproduction leads to higher genetic diversity and potential population fitness (Bijak et al. 
2018), which in turn is essential for meadow resilience.

Research efforts have been increased to understand the processes involved in the sexual reproduction of seagrasses (Orth et al. 2006b; Van Tussenbroek et al. 2009; Kendrick et al. 2012; McMahon et al. 2014) and the role of marine animals in floral or seed predation, pollination, or dispersal of seeds (Van Tussenbroek et al. 2012; Van Tussenbroek \& Muhlia-Montero, 2013; Van Tussenbroek et al. 2016b). Seagrasses have a suite of morphological and anatomical adaptations to enable sexual reproduction in the marine environment (Van Tussenbroek et al. 2009). However, an often-overlooked adaptation to reproduction in the sea is the timing of sexual reproduction.

Seagrass sexual reproduction is synchronized most likely to maximize pollination as a response mechanism to limited pollen dispersal, potential pollen wastage, or flower herbivory (Van Tussenbroek et al. 2008; Van Tussenbroek et al. 2016a). This synchronization in sexual reproduction can occur daily or be caused by environmental cues, such as lunar cycles, tides, and solar radiation (Van Tussenbroek et al. 2009). Synchronization also occurs seasonally and has been reported for species at tropical locations where environmental conditions for sexual reproduction are likely favorable throughout the year (Walker et al. 2001; Van Tussenbroek et al. 2009).
Syringodium filiforme Kützing ("manatee seagrass") is a tropical seagrass found in the western tropical Atlantic from Florida (USA) to Venezuela, including the Gulf of Mexico and the Caribbean Sea, and Bermuda (Short et al. 2010). Classified as a colonizer or opportunistic seagrass, its resistance capacity is low compared to other seagrasses (Bijak et al. 2018; O'Brien et al. 2018b). Population genetics using microsatellite markers has evidenced limited genetic diversity for $S$. filiforme in Florida and the subtropical Atlantic region (Bijak et al. 2018). Syringodium filiforme limited distribution, low genetic diversity, and life strategy highlight the need to further understand its sexual reproductive mechanisms.

This seagrass species reproduces asexually as well as sexually. Asexual reproduction occurs with the horizontal growth of its monopodial rhizome and leads to extensive genetically identical rhizome sections, while sexual reproduction in this dioecious species occurs by pollination of flowers on terminal cymose inflorescences (Tomlinson \& Posluszny, 1978). Sexual reproduction for this species has been reported to occur between January and September at various locations within its distribution range (Table 1). In its northern distribution, this species shows seasonal variation in leaf morphology, productivity, and biomass (Barber \& Behrens, 1985; Fry \& Virnstein, 1988; 
Van Tussenbroek, 1994), as well as sexual reproduction (Zimmerman \& Livingston, 1976; McMillan, 1980). In the Mexican Caribbean, biomass and leaf size of $S$. filiforme are smaller during winter months (Van Tussenbroek 1994). Temperature has been reported as the driving factor for sexual reproduction of $S$. filiforme, which has also been influenced by salinity and photoperiod (McMillan, 1976). However, in the southern distribution, where temperature and photoperiod remain relatively stable throughout the year, the question remains if sexual reproduction of $S$. filiforme occurs consistently throughout the year or it is synchronized, as seen at the more northern locations for this species.

In this study, we identified seasonal patterns in the sexual reproduction of S. filiforme on the continental coast of Costa Rica (latitude $\sim 10^{\circ} \mathrm{N}$ ) in the tropical Caribbean. It was hypothesized that if sexual synchronization were essential for reproductive success for this seagrass species, reproduction would occur at a well-defined period in the year. On the contrary, if synchronization were not essential, then sexual reproduction would occur throughout the year.

\section{MATERIALS AND METHODS}

\section{Study area}

Located on the southern Caribbean coast of Costa Rica ( $9^{\circ} 44^{\prime} 13^{\prime}$ ', N, 82 48' 24"' W) (Fig. 1), Cahuita National Park is a tropical location at a low latitude with warm air temperatures and high amount of light throughout the year (Cortés, 2016; Villalobos-Flores \& Rojas-Morales, 2016). Tidal variation at this location is less than $50 \mathrm{~cm}$, with mixed and semidiurnal tides (Lizano, 2006). Mean annual precipitation at the study site is approximately $3500 \mathrm{~mm}$, with two periods of lower precipitation, the first one in March and the second one in September and October. During the second dry period, runoff is increased overall due to higher precipitation at the catchment level (Villalobos-Flores \& Rojas-Morales, 2016) (Fig. 2). According to historical data, solar radiation, total hours of sunlight, and temperature are at their peak during both dry periods (Villalobos-Flores \& Rojas-Morales, 2016), while tidal range is at its lowest values on both occasions (Fig. 2).

In the Caribbean coast of Costa Rica there are six seagrass species and the most extensive meadows are found in Cahuita and Manzanillo (Samper-Villarreal et al. 2018). In Cahuita, seagrass meadows develop in the reef lagoon formed behind the reef 
Table 1. Sexual reproductive period of S. filiforme in the field reported in the literature

Cuadro 1. El período reproductivo sexual de $S$. filiforme en el campo reportado en la literatura

\begin{tabular}{|c|c|c|c|c|}
\hline Location & $\begin{array}{l}\text { Latitude } \\
\left({ }^{\circ}\right)\end{array}$ & $\begin{array}{l}\text { Sexual reproduction } \\
\text { reported }\end{array}$ & Year sampled & Reference \\
\hline \multicolumn{5}{|c|}{ Gulf of Mexico } \\
\hline \multirow[t]{4}{*}{ Texas } & 27 & May, September & 1974 & McMillan (1976) \\
\hline & 26 & April, May & 1978 & McMillan (1980) \\
\hline & 26 & June & 1978 & McMillan $(1980,1981)$ \\
\hline & 26 & July & 1979 & McMillan (1981) \\
\hline \multirow[t]{9}{*}{ Florida } & 30 & May, June & 1972 & Zimmerman \& Livingston (1976) \\
\hline & 25 & February & 1978 & Tomlinson \& Posluszny (1978) \\
\hline & 25 & May, June & 1979 & McMillan $(1980,1981)$ \\
\hline & 25 & April & 1978 & McMillan (1980) \\
\hline & 24 & February & 1977,1978 & McMillan (1980) \\
\hline & 24 & April & 1978 & McMillan (1980) \\
\hline & 24 & May, June & 1979 & McMillan (1980) \\
\hline & 24 & July & 1916 & Taylor (1928) \\
\hline & 24 & Summer & $1915 \& 1916$ & Bowman (1918) \\
\hline \multicolumn{5}{|c|}{ Caribbean Islands } \\
\hline Jamaica & 18 & February & $\begin{array}{l}\text { sometime between } \\
1974 \text { and 1979) }\end{array}$ & McMillan (1980) \\
\hline \multirow{6}{*}{$\begin{array}{l}\text { US Virgin } \\
\text { Islands }\end{array}$} & 17 & February & $1976,1977,1978$ & McMillan (1980) \\
\hline & 17 & April & 1978 & McMillan (1981) \\
\hline & 17 & May & 1978 & McMillan (1981) \\
\hline & 17 & May, June & 1979 & McMillan $(1980,1981)$ \\
\hline & 17 & April & 1975 & $\begin{array}{l}\text { pers. com. in McMillan (1980, } \\
\text { 1981) }\end{array}$ \\
\hline & 17 & February to May & 1975 & Johnson \& Williams (1982) \\
\hline \multicolumn{5}{|l|}{ Caribbean } \\
\hline \multirow[t]{2}{*}{ Mexico } & 20 & January to July & 1990 to 1991 & Van Tussenbroek (1994) \\
\hline & 19 & March & $\begin{array}{l}\text { sometime between } \\
1974 \text { and 1979) }\end{array}$ & McMillan (1980) \\
\hline Costa Rica & 9 & February \& May & 2010 to 2012 & This study \\
\hline
\end{tabular}




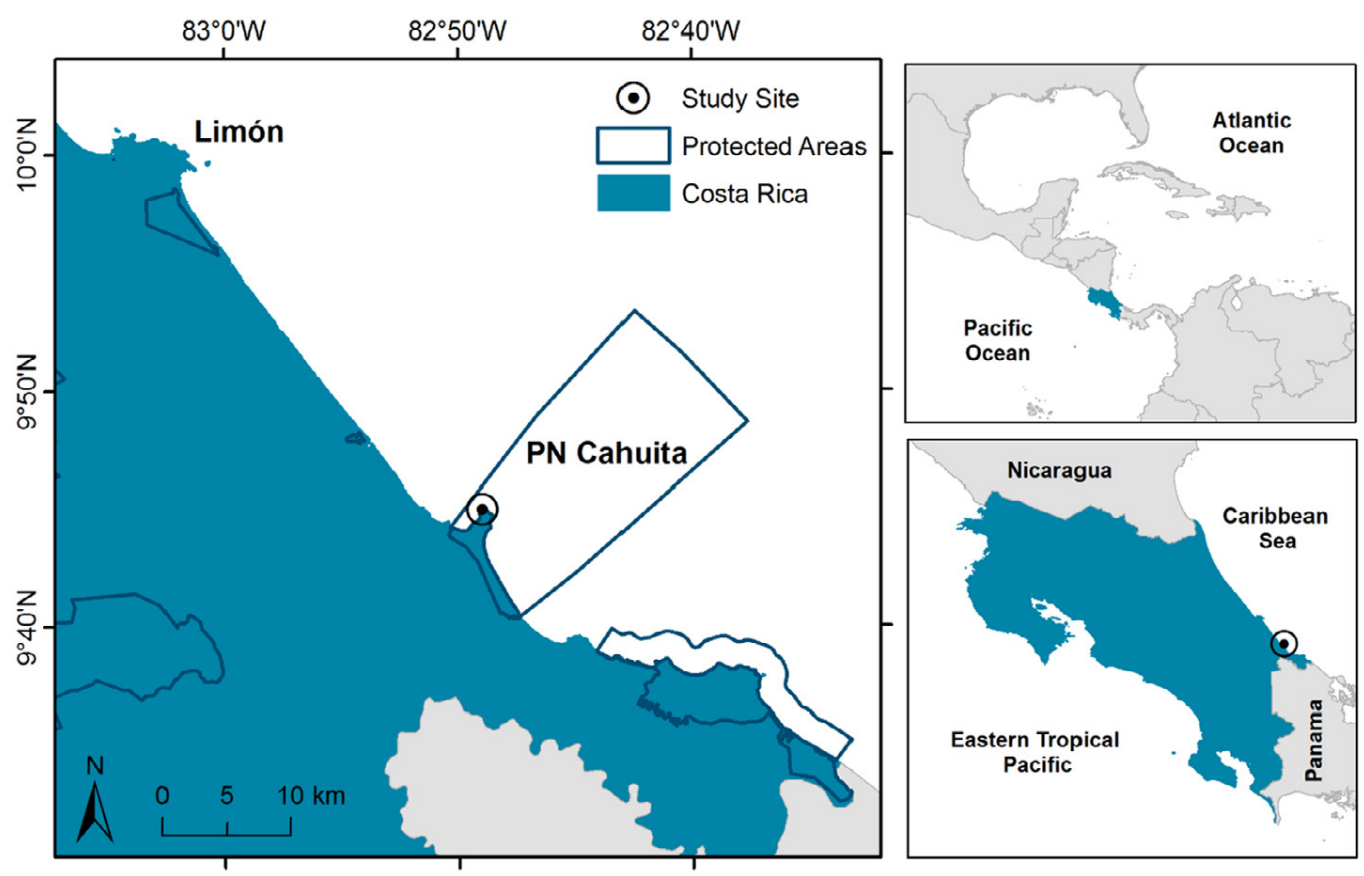

Fig. 1. Location of the seagrass study site on the southern Caribbean coast of Costa Rica. Protected Wildlife Areas from the National System of Conservation Areas of Costa Rica (SINAC) are delimited, highlighting Cahuita National Park

Fig. 1. Ubicación del sitio de estudio en la costa Caribe Sur de Costa Rica. Se delimita las Áreas Protegidas del Sistema Nacional de Áreas de Conservación (SINAC), resaltando el Parque Nacional Cahuita

crest, and Thalassia testudinum is the dominant seagrass species. Seagrasses have been monitored regularly in Cahuita since 1999 as part of the Caribbean Coastal Marine Productivity (CARICOMP) Caribbean-wide monitoring program (Fonseca et al. 2007; Cortés et al. 2010; Loría-Naranjo et al. 2018). At the time of this study, Syringodium filiforme grew in these meadows in dense mono-specific patches (Fig. 3), which grew closer to the beach or in recent sites of disturbance due to small boat anchors. Seagrass patch extension varied slightly among sampling dates due to normal dynamic variability within the meadows (JSV pers. obs.). Sampled seagrasses were monospecific $S$. filiforme patches at $<1 \mathrm{~m}$ depth, constricted to a maximum of $50 \mathrm{~m}$ distance from the shoreline with no evident damage from boat anchors during the sampling period. The sampled location was near the CARICOMP seagrass monitoring location in Cahuita. 

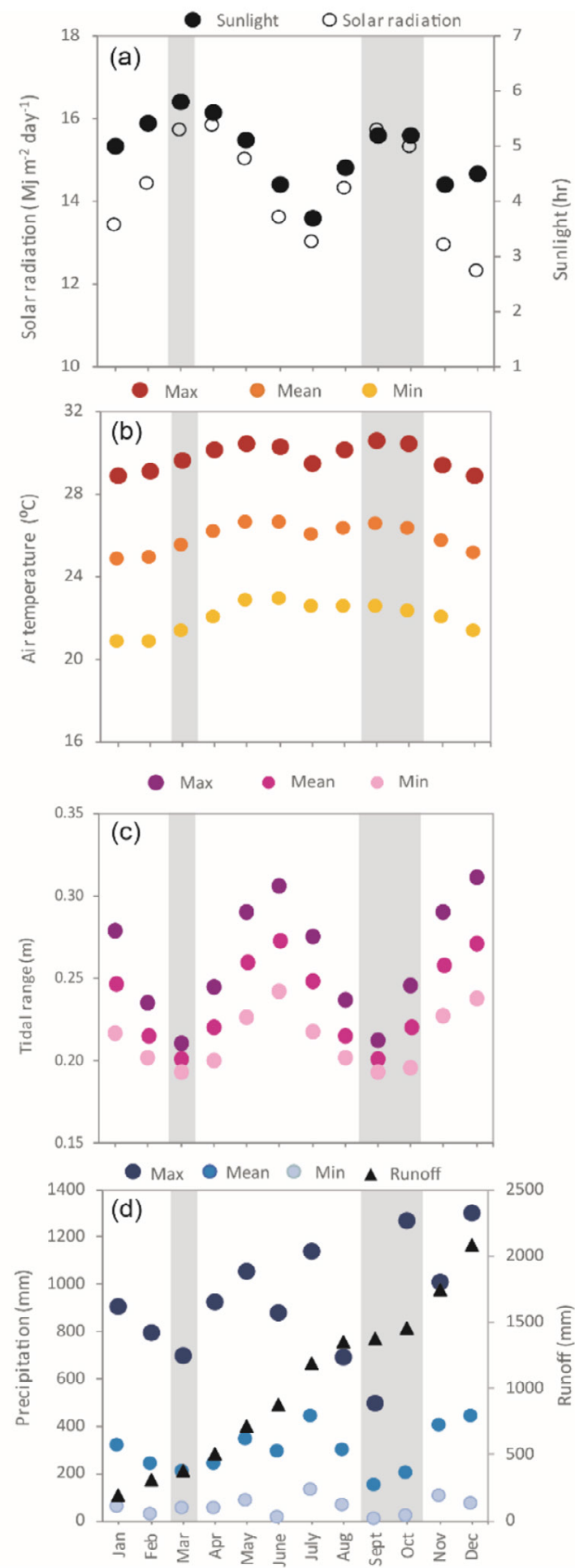

Fig. 2. Average environmental conditions at the study site. Mean solar radiation from 1970 to 2016 and hours of sunlight from 1969 to 2016 per month (A). Mean, maximum and minimum monthly air temperature from 1970 to 2016 (B). Mean, maximum and minimum monthly tidal range at the study site between 1970 and 2016 (C). Mean, maximum and minimum monthly precipitation from 1941 to 2016, and estimated runoff per month (D). Grey shading highlights the two dry seasons at the site. Data sources: IMN, MIO CIMAR, and Villalobos-Flores and Rojas-Morales (2016)

Fig. 2. Condiciones ambientales promedio en el sitio de estudio. Radiación solar promedio desde 1970 hasta el 2016 y horas de luz solar desde 1969 hasta el 2016 por mes (A). Temperatura mensual del aire promedio, máxima y mínima, desde 1970 hasta el 2016 (B). Rango de marea promedio, máximo y mínimo en el sitio de estudio entre 1970 y el 2016 (C). Precipitación mensual promedio, máxima y mínima, desde 1941 hasta el 2016 y escorrentía estimada por mes (D). Las barras grises resaltan los dos períodos secos en el sitio. Fuentes de datos: IMN, MIO-CIMAR y Villalobos-Flores and Rojas-Morales (2016) 

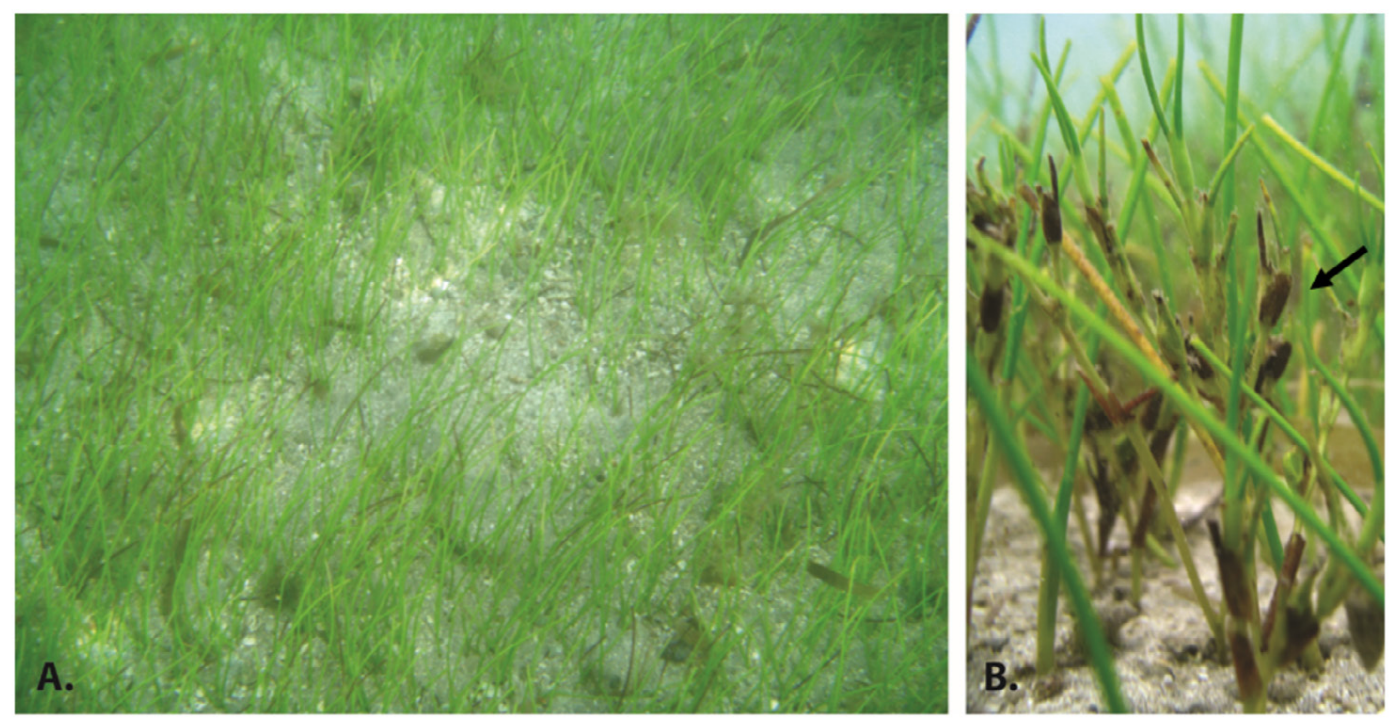

Fig. 3. Seagrass meadows at Cahuita National Park, southern Caribbean coast of Costa Rica. Monospecific patches of the seagrass $S$. filiforme (A); close up of reproductive cymes (B, arrow)

Fig. 3. Praderas de pastos marinos en el Parque Nacional Cahuita, costa Caribe Sur de Costa Rica. Parches monoespecíficos de S. filiforme (A); acercamiento de cimas reproductivas (B, flecha)

Reefs and meadows in Cahuita have been under siltation stress from catchment development and farming for an extended period (Cortés \& Risk, 1985; Cortés et al. 2010), which leads to frequent and high turbidity conditions. These meadows have declined in recent years, in part potentially due to environmental deterioration linked to human activity (Van Tussenbroek et al. 2014).

\section{Seagrass}

The reproductive state and length of $S$. filiforme shoots were recorded in the field between May 2010 and May 2012. Shoots were selected randomly within a $50 \times 50 \mathrm{~m}$ area of the meadow, at approximately $50 \mathrm{~cm}$ minimum distance between subsequent shoots. These non-destructive surveys were done at two-month intervals or at the closest possible date due to frequent challenges regarding environmental conditions that prevented access to the site or field estimations due to high water turbidity. Sexual reproduction was recorded as either reproductive when cymes were present on the shoot or non-reproductive when cymes were absent; cyme sex was not 
recorded. The reproductive state was recorded for 50 shoots on each survey between May 2010 and June 2011. To incorporate shoot length measurements within the available time in the field, the number of shoots to record reproductive state was reduced to 25 shoots between August 2011 and May 2012. Maximum shoot length was determined by measuring the longest leaf with a ruler in situ for 25 shoots per survey between February 2011 and May 2012.

To complement the survey resolution of the study and compare our findings with those of previous collection time periods, we analyzed the presence of reproductive structures in S. filiforme herbarium samples from Cahuita in collections of the National Herbarium of Costa Rica (CR) and the Herbarium of the School of Biology at the University of Costa Rica (USJ).

\section{Environmental variables}

Data on water temperature, salinity, and turbidity was obtained from the CARICOMP monitoring station at this meadow. Water temperature was measured in situ with a Hobo logger (Onset) at 15-min intervals (Fonseca et al. 2007; Cortés et al. 2010). Salinity was measured in the lab using a hand-held refractometer (ATAGO) from a subsurface $\sim 50 \mathrm{~mL}$ water sample collected at the site. Given that the shallow depth of the site was frequently less than the Secchi measurements, water turbidity was estimated with horizontal Secchi disk measurements, parallel to the sea floor. Secchi measurements were carried out at least four times at each survey, once towards each cardinal point. Water salinity and turbidity were measured to incorporate short-term variability on additional dates whenever possible, associated with other projects conducted in the meadow. Tidal range was defined as the variation of subsequent tides. Tidal data was provided by the Oceanographic Information Module at the Research Center for Marine Sciences and Limnology (Módulo de Información Oceanográfica-Centro de Investigación en Ciencias del Mar y Limnología, MIO-CIMAR). Monthly total precipitation was obtained from the nearest station (Limón) of the Costa Rican National Meteorological Institute (Instituto Meteorológico $\mathrm{Na}$ cional, IMN) and previous publications on Costa Rican Caribbean climate (Villalobos-Flores \& Rojas-Morales, 2016).

\section{Data analysis}

Variability in shoot reproductive state and frequency of reproductive shoots among surveyed months were analyzed using linear models with Tukey post hoc analyses. Shoot length variability and its relationship with mean water temperature, salinity, turbidity, and precipitation for the surveyed months were analyzed using linear mixed effects models (LMER) with maximum likelihood and date as 
the random effect (Bates et al. 2012). Variability in water salinity, turbidity, and temperature between months and years was also analyzed using LMER. This approach accounted for the non-independence of data. Given the limited number of samples, linear regressions were used to analyze the relationship between reproductive frequency and leaf length, mean monthly salinity, water temperature and turbidity, as well as total precipitation. Tidal range variability was analyzed per month with LMER, with year and day as random effects. All analyses were conducted in R v.3.2.5 (R Development Core Team, 2012). Normality and homoscedasticity of model residuals were determined by visual estimation of "Quantile-Quantile" and "Residuals vs Fitted" plots (Crawley, 2007).

\section{RESULTS}

Seagrass sexual reproduction and length

Sexual reproduction of $S$. filiforme showed a punctuated reproduction period, with cymes present in February and May and consistently absent during the other sampling dates (Table 2). When reproductive cymes were present, the frequency of reproductive shoots was between 8 and $38 \%$ (Table 2). Shoot length of $S$. filiforme showed no variability among sampled months $\left(\mathrm{x}^{2}=4.7, \mathrm{df}=\right.$ $4, P=0.3$, Table 2), and ranged from 4 to $36 \mathrm{~cm}$. There was no significant correlation between the frequency of reproductive shoots and shoot length $(\mathrm{r}=0.4, P=0.5, \mathrm{n}=6)$.

Table 2. Syringodium filiforme shoot length and reproductive frequency measured in situ per sampling date between 2010 and 2012 (mean \pm standard deviation). Cahuita National Park, southern Caribbean of Costa Rica. (-) no data Cuadro 2. Longitud de haces y frecuencia reproductiva de $S$. filiforme medidas in situ por fecha de muestreo entre 2010 y 2012 (promedio \pm desviación estándar). Parque Nacional Cahuita, Caribe Sur de Costa Rica. (-) sin datos

\begin{tabular}{|c|c|c|c|c|c|c|}
\hline & February & May & June & August & October & November \\
\hline \multicolumn{7}{|c|}{$\begin{array}{l}\text { Reproductive } \\
\text { frequency }(\%)\end{array}$} \\
\hline 2010 & - & 38 & - & 0 & 0 & 0 \\
\hline 2011 & 20 & - & 0 & 0 & 0 & - \\
\hline 2012 & 8 & 28 & - & - & - & - \\
\hline \multicolumn{7}{|c|}{ Shoot length $(\mathrm{cm})$} \\
\hline 2011 & $14 \pm 4$ & - & $17 \pm 3$ & $13 \pm 5$ & $17 \pm 4$ & - \\
\hline 2012 & $20 \pm 3$ & $21 \pm 7$ & - & - & - & - \\
\hline
\end{tabular}




\section{Environmental variables}

Water salinity, turbidity and temperature varied among the months surveyed at the study site. Salinity was lowest in April $\left(\mathrm{x}^{2}=55.0, \mathrm{df}=9, P<\right.$ 0.001 , Fig. 4) while water was more turbid in December compared to other months $\left(\mathrm{x}^{2}=57.5, \mathrm{df}=9, P<0.001\right.$, Fig. 4). Water temperature was the coldest at the beginning and the end of the year $\left(\mathrm{x}^{2}=67.526, \mathrm{df}=9, P<\right.$ 0.001 , Fig. 4).
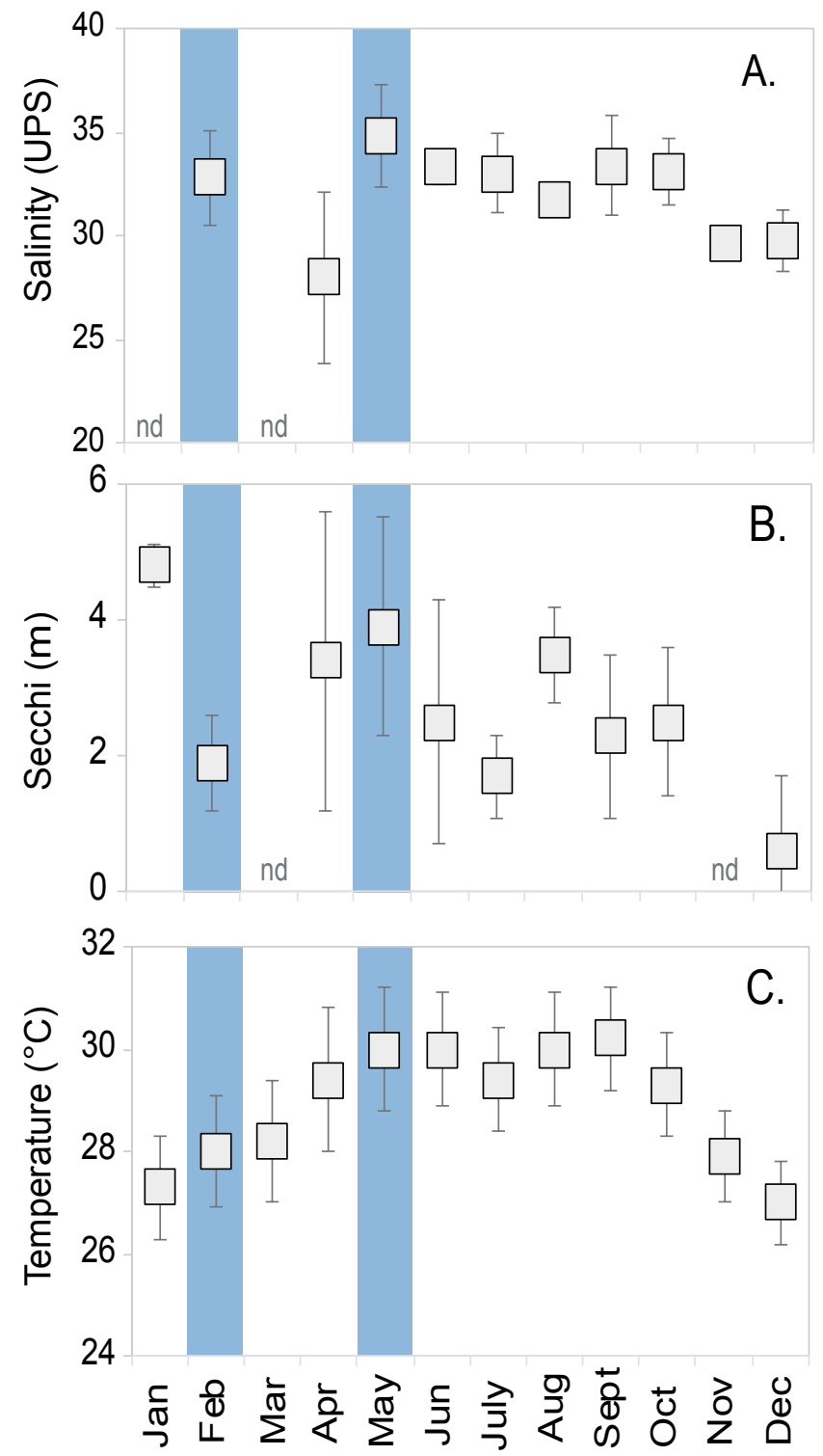

Fig. 4. Water salinity (A), turbidity measured with Secchi disk (B), and temperature (C) measured in situ per sampling date between 2010 and 2012 (mean \pm standard deviation). Cahuita National Park, southern Caribbean of Costa Rica. (nd) no data. Salinity $n=$ between 3 and 6 per month. Turbidity (Secchi) $\mathrm{n}=$ between 5 and 10 per month. The reproductive periods found in this study are highlighted in light blue

Fig. 4. Salinidad (A), turbidez medida con el disco Secchi (B) $\mathrm{y}$ temperatura (C), medidos in situ por fecha de muestreo entre 2010 y 2012 (promedio \pm desviación estándar). Parque Nacional Cahuita, Caribe Sur de Costa Rica. (nd) sin datos. Salinidad $n=$ entre 3 y 6 por mes. Turbidez (Secchi) $\mathrm{n}=$ entre 5 y 10 por mes. Períodos reproductivos encontrados en este estudio están resaltados en celeste 
The frequency of $S$. filiforme reproductive shoots was not explained by water column temperature $(\mathrm{r}=0.1$; $P=0.7)$, salinity $(\mathrm{r}=0.3 ; P=0.4)$, turbidity ( $\mathrm{r}=0.2 ; P=0.6)$, or monthly total precipitation $(\mathrm{r}=0.2 ; P=0.5)$. Shoot length showed no relationship with water temperature $\left(\mathrm{x}^{2}=0.0, \mathrm{df}=\right.$ $4, P=0.9)$, water turbidity $\left(\mathrm{x}^{2}=0.0, \mathrm{df}\right.$ $=4, P=0.9)$, or total monthly precipitation $\left(\mathrm{x}^{2}=0.3 \mathrm{df}=4, P=0.6\right)$. Shoot length did increase slightly at higher salinity levels $\left(\mathrm{x}^{2}=8.5\right.$, $\mathrm{df}=4, P<$ $0.01)$, despite the lack of clear patterns between turbidity and salinity $(\mathrm{r}=0.1$; $P=0.8)$, turbidity and precipitation ( $\mathrm{r}$ $=-0.4 ; P=0.3$ ), or salinity and precipitation $(\mathrm{r}=-0.4 ; P=0.2)$. Tidal range was smaller during both dry seasons throughout the year $\left(\mathrm{x}^{2}=1904.8, \mathrm{df}=\right.$ $12, P<0.01$; Fig. 2).

\section{DISCUSSION}

Sexual reproduction of $S$. filiforme was synchronized at our tropical location in the southern Caribbean, without a clear link to the environmental triggers measured. Reproductive cymes were present in February and May, while cymes were consistently absent in June, August, October, and November between 2010 and 2012 at this tropical site. The reproductive period for $S$. filiforme in the Caribbean and the Gulf of Mexico is between January and September (Table 1). The timing of $S$. filiforme reproduction found at this tropical location fell within the total reproductive season for this species. The survey resolution of our study was affected by periods of increased wave energy, lightning storms, and diminished water clarity due to increased precipitation, which did not allow access to the field site or data collection once in the field on multiple dates. Therefore, flowering outside the surveyed dates of the study may have been missed, and more detailed phenological studies of $S$. filiforme should be conducted at increased temporal resolutions at tropical locations.

In August 1983 (CR-138191) and November 1972 (CR-50020) only vegetative shoots were collected at this tropical site, which coincides with our findings reflecting a lack of reproductive structures at Cahuita during those months. Vegetative shoots were also collected in January 2008 (USJ-92780) and July 1962 (Den Hartog, 1970), which were months not surveyed in this study. Reproductive shoots were collected in February (USJ-104919 and duplicates) and May 2004 (USJ104913), also coinciding with our observations on the timing of $S$. filiforme reproductive state in the field. Reproductive samples were also collected in March 2005 (USJ-104921), April 1982 (USJ-037843), and July 1992 (CR-167852). This data fell outside our surveyed months and may indicate that the seasonal period extends from February to July. In contradiction 
to this proposed reproductive period, only vegetative samples were collected in April 1978 (USJ-017312) and 2012 (CR-273679). This might indicate that reproductive efforts may potentially vary among years or spatially within the same meadow.

Small scale spatial variability of environmental conditions may lead to variations in flowering frequency. In St. Croix, sexual reproduction of $S$. filiforme has varied from meadow to meadow at different depths or locations, some flowering very frequently to others flowering rarely (McMillan, 1980). In a coastal fringe in the Mexican Caribbean, average $S$. filiforme density was 412 cymes $\mathrm{m}^{-2}$, varying between only 11 cymes $m^{-2}$ up to 1067 cymes $\mathrm{m}^{-2}$ (Van Tussenbroek \& Muhlia Montero, 2013). The type of sediment at each meadow has also been suggested as a potential factor in the reproductive frequency, with higher fecundities in coarser sediments and lower fecundities in silty sediments (McMillan, 1980). At our study site, reproductive frequency was only between $8 \%$ and $38 \%$, even when flowering cymes were noted in the field. Therefore, there appears to be small scale spatial variability in $S$. filiforme flowering within our study site. It is possible that, when herbarium samples were collected in April, reproductive cymes could have been present yet not collected.
In contrast to locations at higher latitudes, environmental conditions at this tropical site were likely favorable for sexual reproduction throughout the year or at least during both dry periods. Contrasting these homogeneous conditions, $S$. filiforme reproductive cymes were only found in a limited time period; therefore, flowering could not be fully explained by the environmental variables analyzed. Although flowering coincided with the first dry period of the year at this location, sexual reproduction of $S$. filiforme did not occur during the second dry period. The first dry period occurred after increasing solar radiation and a slight rise in water temperature since the beginning of January, which may have influenced the onset of the flowering season. The second dry period had increased runoff conditions due to higher precipitation in the mountainous upper catchments, while the coastal region experiences drier conditions. This increased runoff may not be conducive to reproductive efforts. The absence of reproductive cymes during the second dry period at our tropical location, despite favorable conditions, suggests that the reproductive cycle of $S$. filiforme is regulated. Such marked programming is possibly necessary to synchronize male and female reproductive functions due to pollen limitation, as suggested by Van Tussenbroek et al. (2008) and Van Tussenbroek et al. (2016a). Future studies on this topic for S. filiforme should 
provide further details on flower sex and apply experimental approaches.

Another potential factor influencing flowering of $S$. filiforme is nutrient availability, which may be linked to catchment effluent input. Sexual reproduction of $S$. filiforme has been reported to occur at higher frequencies under limited nutrient conditions, with high nitrogen inhibiting flowering under controlled laboratory conditions (McMillan, 1980). However, higher concentrations of ammonium in sediment pore water led to higher flowering frequencies for a larger temperate seagrass, Zostera, under long-term conditions, but less marked in shorter experimental exposure periods (Johnson et al. 2017). Therefore, the specific effect of nutrient concentration on seagrass flowering may potentially differ among species, length of the nutrient loading or deprivation event, and/or locations.

In colder regions of the Greater Caribbean, such as northern Florida, $S$. filiforme reproduction may not occur, even during summer, unless during exceptionally warm years (Gilbert \& Clark, 1981). Anomalous timing of reproduction of $S$. filiforme was reported at a tropical location in Mexico following the passing of a strong Hurricane (Wilma), which led to an abrupt $10^{\circ} \mathrm{C}$ decline in sea water temperature and the subsequent flowering of $S$. filiforme in December of 2005, approximately eight weeks earlier than usual for that location. The S. filiforme reproductive period in our study follows the coldest months for this tropical location (Table 2, Fig. 2). The limited variation in average temperature found at our tropical study site $\left(27-30^{\circ} \mathrm{C}\right.$ minmax, Fig. 2), albeit much smaller than in subtropical locations (i.e. $9-31^{\circ} \mathrm{C}$, Zimmerman \& Livingston, 1976), may be enough to trigger sexual reproduction. Previous experimental studies on S. filiforme flowering found that this seagrass could be induced to flower at specific temperatures $\left(20-24^{\circ} \mathrm{C}\right)$, yet the specific temperature triggering flowering depended on the location the plant had been collected (McMillan, 1980). Follow-up manipulative experiments of varying ranges of variability in the field or in an aquarium setting would help clarify the specific role of temperature fluctuations as an environmental trigger of sexual reproduction in S. filiforme at lower latitudes.

Light availability may also influence sexual reproduction at this tropical Caribbean location, although it is a multicausal condition at this site with high variability. During the study, cyme production coincided with yearly increased number of hours of available light i.e. photoperiod and light intensity. Photoperiod variations have been shown to affect sexual reproduction of $S$. filiforme in a controlled laboratory study (McMillan, 1980). However, seagrasses have been triggered to flower under continuous light 
conditions, which indicates that other factors are also involved under sufficient available light (McMillan, 1982). In contrast to high light availability during the first dry period, conditions for most of the year include high precipitation at the study site or further up the catchment and subsequent runoff input (Villalobos-Flores \& Rojas-Morales, 2016), limiting light availability for seagrasses.

There also appears to be high short-term variation in light availability at our study site, in part due to pulsed catchment effluent input and increased wind and wave energy leading to resuspension of fine sediment (JSV pers. obs.). The flowering frequency of the temperate seagrass Zostera is known to diminish under long-term shaded conditions (Johnson et al. 2017). Seagrass response to diminished light availability can vary within seagrass meadows, and $S$. filiforme, as a colonizing seagrass species, has lower tolerance for light deprivation than more persistent seagrass species (O'Brien et al. 2018a). Sexual reproduction for the development of a seed bank prior to periods of diminished environmental conditions, including light deprivation, is a recovery strategy reported for other tropical seagrasses (Rasheed et al. 2014). In contrast to more temperate locations, conditions near the Equator may be suitable with abundant light all year round. Nonetheless, temporal variation of light availability is a complex and multicausal factor.

The sexual reproduction of S. filiforme also coincided with one of two periods of lowest and more stable tidal ranges. The tidal variation on the Caribbean coast of Costa Rica is less than 50 $\mathrm{cm}$ and sometimes is mixed and others semidiurnal (Lizano, 2006). Overall, the Caribbean is microtidal, with variations of 10 to $20 \mathrm{~cm}$ (Kjerfve, 1981). Higher fecundity rates of $S$. filiforme have been reported in St. Croix meadows near the low tide line (McMillan, 1980). Thalassia testudinum sexual reproduction is also synchronized in our study location, occurring between March and August (Nielsen-Muñoz \& Cortés, 2008; Cortés et al. 2010), similar to $S$. filiforme, at the lowest tides of the year (Nielsen-Muñoz \& Cortés, 2008). Further analyses are needed to understand the underlying mechanisms of tidal variation as a triggering factor for seagrass sexual reproduction at tropical latitudes.

There was no variability in $S$. filiforme shoot length between the months surveyed, in contrast with the seasonality found in other parts of the Caribbean. Seasonal variation in leaf dynamics (Barber \& Behrens, 1985; Fry \& Virnstein, 1988; Short et al. 1993) and biomass (Van Tussenbroek, 1994) have been reported in more northern locations. At the study location, $T$. testudinum leaf dynamics show intra- and inter-annual variation 
(Loría-Naranjo et al. 2018), with biomass and productivity reported to decrease at higher temperatures (Cortés et al. 2010). The reasons for a lack of variation in S. filiforme shoot length during our study remain unclear, and potential confounding factors such as grazing dynamics (Valentine \& Duffy, 2006) should be assessed at this study site.

Seagrass conservation and management efforts should consider seagrass species reproduction and dispersal mechanisms, which are potential key factors in seagrass genetic variability and meadow resilience. The punctuated sexual reproduction of two seagrass species at this site close to the equator, with much more subtle environmental forcing than those in higher latitudes, is interesting and merits further investigation on the mechanisms and possible adaptive advantage of synchronized reproduction in seagrasses.

\section{ACKNOWLEDGEMENTS}

This study was funded by Vicerrectoría de Investigación and Centro de Investigación en Ciencias del Mar y Limnología (CIMAR) at Universidad de Costa Rica. This work was supported by CARICOMP monitoring program in Costa Rica (CIMAR project 808-96-298). We would like to thank the assistants and volunteers that helped during the sampling period.
The environmental data was provided by IMN and tide data was provided by the MIO module at CIMAR. We would also like to thank the local community of Cahuita, the personnel at Cahuita National Park, and the administrative staff at CIMAR for their support throughout the project.

\section{REFERENCES}

Ackerman, J. D. (2006). Sexual reproduction of seagrasses: pollination in the marine context. In A. Larkum, R. Orth \& C. Duarte (Eds.), Seagrasses: Biology, Ecology and Conservation (pp. 89109). The Netherlands: Springer.

Barber, B. J. \& Behrens, P. J. (1985). Effects of elevated temperature on seasonal in situ leaf productivity of Thalassia testudinum Banks ex König and Syringodium filiforme Kützing. Aquat. Bot., 22(1), 61-69. https://doi. org/10.1016/0304-3770(85)90029-4

Bates, D., Maechler, M. \& Bolker, B. (2012). lme4: Linear mixed-effects models using S4 classes. R package version 0.999999-0.

Bijak, A. L., Van Dijk, K. \& Waycott, M. (2018). Population structure and gene flow of the tropical seagrass, Syringodium filiforme, in the Florida Keys and subtropical Atlantic region. PloS ONE, 13(9), e0203644. https://doi. org/10.1371/journal.pone.0203644

Bowman, H. H. M. (1918). Botanical ecology of the Dry Tortugas. Pap. Mar. Biol. Carnegie Inst. Wash., 12, 111-137.

Cortés, J. (2016). The Caribbean coastal and marine ecosystems. In M. Kappelle (Ed.), Costa Rican Ecosystems (pp. 591-617). Chicago: University of 
Chicago Press. https://doi.org/10.7208/ chicago/9780226121642.003.0017

Cortés, J., Fonseca, A. C., Nivia-Ruiz, J., Nielsen-Muñoz, V., Samper-Villarreal, J., Salas, E.... \& Zamora-Trejos, P. (2010). Monitoring coral reefs, seagrasses and mangroves in Costa Rica (CARICOMP). Rev. Biol. Trop., 58(Suppl. 3), 1-22.

Cortés, J. \& Risk, M. J. (1985). A reef under siltation stress: Cahuita, Costa Rica. Bull. Mar. Sci., 36(2), 339-356.

Crawley, M. J. (2007). The $R$ book. England: John Wiley \& Sons. https://doi. org/10.1002/9780470515075

Den Hartog, C. (1970). The Sea-Grasses of the World. The Netherlands and England: North-Holland Publishing Company.

Fonseca, A. C., Nielsen, V. \& Cortés, J. (2007). Monitoreo de pastos marinos en Perezoso, Cahuita, Costa Rica (sitio CARICOMP). Rev. Biol. Trop., 55(1), 55-66.

Fry, B. \& Virnstein, R. W. (1988). Leaf production and export of the seagrass Syringodium filiforme Kütz. in Indian River Lagoon, Florida. Aquat. Bot., 30(3), 261-266. https://doi. org/10.1016/0304-3770(88)90057-5

Gilbert, S. \& Clark, K. B. (1981). Seasonal variation in standing crop of the seagrass Syringodium filiforme and associated macrophytes in the Northern Indian River, Florida. Estuaries, 4(3), 223225. https://doi.org/10.2307/1351479

James, R. K., Silva, R., Van Tussenbroek, B. I., Escudero-Castillo, M., Mariño-Tapia, I., Dijkstra, H. A... \& Bouma, T. J. (2019). Maintaining tropical beaches with seagrass and algae: a promising alternative to engineering solutions. BioScience, 69(2), 136-142. https://doi. org/10.1093/biosci/biy154

Johnson, A. J., Moore, K. A. \& Orth, R. J. (2017). The influence of resource availability on flowering intensity in Zostera marina (L.). J. Exp. Mar. Biol. Ecol., 490, 13-22. https://doi. org/10.1016/j.jembe.2017.02.002

Johnson, E. A. \& Williams, S. (1982). Sexual reproduction in seagrasses: reports for five Caribbean species with details for Halodule wrightii Aschers and Syringodium filiforme Kütz. Carib. J. Sci., 18(1-4), 61-70.

Kendrick, G. A., Duarte, C. M. \& Marbà, N. (2005). Clonality in seagrasses, emergent properties and seagrass landscapes. Mar. Ecol. Prog. Ser., 290, 291-296.

https://doi.org/10.3354/ meps 290291

Kendrick, G. A., Waycott, M., Carruthers, T. J., Cambridge, M. L., Hovey, R., Krauss, S. L. ... \& i Vidal, O. M. (2012). The central role of dispersal in the maintenance and persistence of seagrass populations. BioScience, 62(1), 56-65. https://doi.org/10.1525/ bio.2012.62.1.10

Kjerfve, B. (1981). Tides of the Caribbean Sea. J. Geophys. Res. 86(C5), 4243-4247. https://doi.org/10.1029/ JC086iC05p04243

Lizano, O. G. (2006). Algunas características de las mareas en la costa Pacífica y Caribe de Centroamérica. Ciencia y Tecnología, 24(1), 51-64.

Loría-Naranjo, M., Samper-Villarreal, J., Sandoval-Siles, M. \& Cortés, J. (2018). Intra- and inter-annual variation in a seagrass meadow on the Caribbean coast of Costa Rica: 2009-2015. Rev. Biol. Trop., 66(3), 1149-1161. https:// doi.org/10.15517/rbt.v66i3.31035

Marbà, N. \& Walker, D. I. (1999). Growth, flowering, and population dynamics of temperate Western Australian seagrasses. Mar. Ecol. Prog. Ser., 184, 105-118. https://doi.org/10.3354/meps 184105 
McMahon, K., Van Dijk, J. K., Ruiz-Montoya, L., Kendrick, G. A., Krauss, S. L., Waycott, M... \& Duarte, C. (2014). The movement ecology of seagrasses. Proc. R. Soc. London, Ser. B, 281, 20140878. https://doi.org/10.1098/ rspb.2014.0878

McMillan, C. (1976). Experimental studies on flowering and reproduction in seagrasses. Aquat. Bot., 2, 87-92. https://doi. org/10.1016/0304-3770(76)90011-5

McMillan, C. (1980). Reproductive physiology in the seagrass, Syringodium filiforme, from the Gulf of Mexico and the Caribbean. Am. J. Bot., 67(1), 104-110. https://doi. org/10.1002/j.1537-2197.1980. tb07628.x

McMillan, C. (1981). Seed reserves and seed germination for two seagrasses, Halodule wrightii and Syringodium filiforme, from the western Atlantic. Aquat. Bot., 11, 279-296. https:// doi.org/10.1002/j.1537-2197.1980. tb07628.x

McMillan, C. (1982). Reproductive physiology of tropical seagrasses. Aquat. Bot., 14, 245-258. https://doi. org/10.1016/0304-3770(82)90102-4

Nielsen-Muñoz, V. \& Cortés, J. (2008). Abundancia, biomasa y floración de Thalassia testudinum (Hydrocharitaceae) en el Caribe de Costa Rica. Rev. Biol. Trop., 56(Suppl. 4), 175-189.

Nordlund, L. M., Jackson, E. L., Nakaoka, M., Samper-Villarreal, J., Beca-Carretero, P. \& Creed, J. C. (2018). Seagrass ecosystem services - what's next? Mar. Pollut. Bull, 134, 145-151. https://doi. org/10.1016/j.marpolbul.2017.09.014

O’Brien, K. R., Adams, M. P., Ferguson, A. J., Samper-Villarreal, J., Maxwell, P. S., Baird, M. E. \& Collier, C. (2018a). Seagrass resistance to light deprivation: Implications for resilience. In A. W. D. Larkum, G. A. Kendrick \& P. J. Ralph (Eds.), Seagrasses of Australia (pp. 287-311). The Netherlands: Springer. https://doi. org/10.1007/978-3-319-71354-0_10

O’Brien, K. R., Waycott, M., Maxwell, P., Kendrick, G. A., Udy, J. W., Ferguson, A. J. ... \& Dennison, W. C. (2018b). Seagrass ecosystem trajectory depends on the relative timescales of resistance, recovery and disturbance. Mar. Pollut. Bull, 134, 166-176. https://doi. org/10.1016/j.marpolbul.2017.09.006

Orth, R. J., Carruthers, T. J. B., Dennison, W. C., Duarte, C. M., Fourqurean, J. W. ... \& Olyarnik, S. (2006a). A global crisis for seagrass ecosystems. BioScience, 56(12), 987-996. https://doi. org/10.1641/0006-3568(2006)56[987 :AGCFSE]2.0.CO;2

Orth, R. J., Harwell, M. C. \& Inglis, G. J. (2006b). Ecology of seagrass seeds and seagrass dispersal processes. In A. Larkum, R. Orth \& Duarte, C. (Eds.), Seagrasses: Biology, Ecology and Conservation (pp. 111-133). The Netherlands: Springer.

R Development Core Team. (2012). R: A language and environment for statistical computing. R Foundation for Statistical Computing. Vienna, Austria. Retrieved from http://www.R-project.org/

Rasheed, M. A., McKenna, S. A., Carter, A. B. \& Coles, R. G. (2014). Contrasting recovery of shallow and deep water seagrass communities following climate associated losses in tropical north Queensland, Australia. Mar. Pollut. Bull., 83, 491-499. https://doi. org/10.1016/j.marpolbul.2014.02.013

Samper-Villarreal, J., Van Tussenbroek, B. I. \& Cortés, J. (2018). Seagrasses of Costa Rica: from the mighty Caribbean to the dynamic meadows of the Eastern Tropical Pacific. Rev. Biol. Trop., 
66(Suppl. 1), S53-S65. https://doi. org/10.15517/rbt.v66i1.33260

Short, F. T., Carruthers, T. J. R., van Tussenbroek, B. \& Zieman, J. (2010). Syringodium filiforme. The IUCN Red List of Threatened Species. e. T173378A7003203. http://dx.doi. org/10.2305/IUCN.UK.2010-3.RLTS. T173378A7003203.en

Short, F. T., Montgomery, J., Zimmermann, C. \& Short, C. (1993). Production and nutrient dynamics of a Syringodium filiforme Kütz. Seagrass bed in Indian River Lagoon, Florida. Estuaries, 16(2), 323-334. https://doi. org/10.2307/1352505

Taylor, W. R. (1928). The marine algae of Florida with special reference to the Dry Tortugas. USA: Carnegie Institution of Washington.

Tomlinson, P. B. \& Posluszny, U. (1978). Aspects of floral morphology and development in the seagrass Syringodium filiforme (Cymodoceaceae). Bot. Gaz., 139(3), 333-345. https://doi. org/10.1086/337009

Valentine, J. F. \& Duffy, J. E. (2006). The central role of grazing in seagrass ecology. In A. Larkum, R. Orth \& C. Duarte (Eds.), Seagrasses: Biology, Ecology and Conservation (pp. 463-501). The Netherlands: Springer.

Van Tussenbroek, B. I. (1994). Spatial and seasonal variability in biomass and leaf morphology of the manatee grass, $S y$ ringodium filiforme in a tropical coral reef lagoon, Mexico. An. Inst. Cienc. Mar Limnol. UNAM, 1-2, 1-13.

Van Tussenbroek, B. I., Cortés, J., Collin, R., Fonseca, A. C., Gayle, P. M. H., Guzmán, H. M.... \& Weil, E. (2014). Caribbean-wide, long-term study of seagrass beds reveals local variations, shifts in community structure and occasional collapse. PLoS ONE, 9(3), e90600. https://doi.org/10.1371/journal.pone.0090600

Van Tussenbroek, B. I., Márquez-Guzman, J. \& Wong, R. (2009). Phenology of marine angiosperms (seagrasses): reproductive synchrony in the sea. In A. Gamboa-deBuen, A. Orozco-Segovia \& F. Cruz-García (Eds.), Functional Diversity of Plant Reproduction (pp. 17-46). India: Research Singpost.

Van Tussenbroek, B. I., Monroy-Velazquez, L. V. \& Solis-Weiss, V. (2012). Meso-fauna foraging on seagrass pollen may serve in marine zoophilous pollination. Mar. Ecol. Prog. Ser., 469, 1-6. https:// doi.org/10.3354/meps 10072

Van Tussenbroek, B. I. \& Muhlia-Montero, M. (2013). Can floral consumption by fish shape traits of seagrass flowers? Evol. Ecol., 27(2), 269-284. https://doi. org/10.1007/s10682-012-9600-4

Van Tussenbroek, B. I., Soissons, L. M., Bouma, T. J., Asmus, R., Auby, I., Brun, F. G... \& Ganthy, F. (2016a). Pollen limitation may be a common Allee effect in marine hydrophilous plants: implications for decline and recovery in seagrasses. Oecologia, 182(2), 595-609. https://doi.org/10.1007/ s00442-016-3665-7

Van Tussenbroek, B. I., Villamil, N., Márquez-Guzmán, J., Wong, R., Monroy-Velázquez, L. V. \& Solis-Weiss, V. (2016b). Experimental evidence of pollination in marine flowers by invertebrate fauna. Nat. Commun., 7, 12980. https://doi.org/10.1038/ncomms12980

Van Tussenbroek, B. I., Wong, J. R. \& Márquez-Guzman, J. (2008). Synchronized anthesis and predation on pollen in the marine angiosperm Thalassia testudinum (Hydrocharitaceae). Mar. Ecol. Prog. Ser., 354, 119-124. https:// doi.org/10.3354/meps07212 
Villalobos-Flores, R. \& Rojas-Morales, N. (2016). Descripción del Clima Cantón de Limón. Costa Rica: Instituto Meteorológico Nacional (IMN), Ministerio Nacional del Ambiente y Energía (MINAE) de Costa Rica.

Walker, D. I., Olesen, B. \& Phillips, R. C. (2001). Reproduction and phenology in seagrasses. In F. Short \& R. Coles (Eds.), Global Seagrass Research Methods (Vol. 33, pp. 5978). The Netherlands: Elsevier Science B.V. https://doi.org/10.1016/ B978-044450891-1/50004-9

Waycott, M., Duarte, C. M., Carruthers, T. J. B., Orth, R. J., Dennison, W. C., Olyarnik, S... \& Hughes, A. R. (2009). Accelerating loss of seagrasses across the globe threatens coastal ecosystems. Proc. Natl. Acad. Sci. U.S.A., 106(30), 12377-12381. https://doi.org/10.1073/ pnas.0905620106

Waycott, M., Procaccini, G., Les, D. H. \& Reusch, T. B. (2006). Seagrass evolution, ecology and conservation: a genetic perspective. In A. Larkum, R. Orth \& C. Duarte (Eds.), Seagrasses: Biology, Ecology and Conservation (pp. 25-50). The Netherlands: Springer.

Zimmerman, M. S. \& Livingston, R. J. (1976). Seasonality and physico-chemical ranges of benthic macrophytes from a north Florida estuary (Apalachee Bay). Contrib. Mar. Sci., 20, 33-45. 